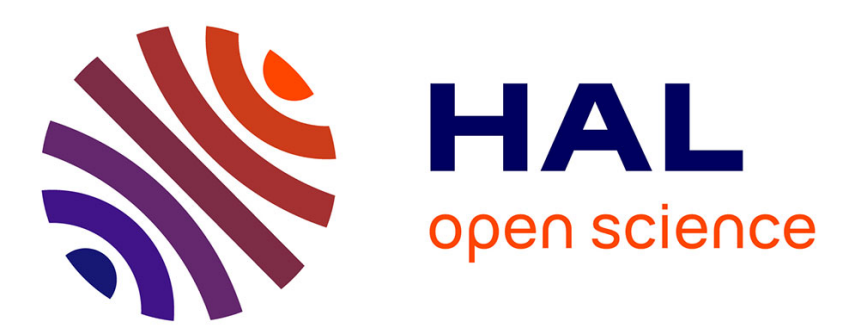

\title{
NEW GREEN EMISSION IN Ce3+ DOPED YTTRIUM ALUMINIUM PEROVSKITE
}

J. Mares, M. Nikl, K. Blazek

\section{To cite this version:}

J. Mares, M. Nikl, K. Blazek. NEW GREEN EMISSION IN Ce3+ DOPED YTTRIUM ALUMINIUM PEROVSKITE. Journal de Physique IV Proceedings, 1991, 01 (C7), pp.C7-421-C7-421. 10.1051/jp4:19917109 . jpa-00250757

\section{HAL Id: jpa-00250757 https://hal.science/jpa-00250757}

Submitted on 1 Jan 1991

HAL is a multi-disciplinary open access archive for the deposit and dissemination of scientific research documents, whether they are published or not. The documents may come from teaching and research institutions in France or abroad, or from public or private research centers.
L'archive ouverte pluridisciplinaire HAL, est destinée au dépôt et à la diffusion de documents scientifiques de niveau recherche, publiés ou non, émanant des établissements d'enseignement et de recherche français ou étrangers, des laboratoires publics ou privés. 


\title{
NEW GREEN EMISSION IN Ce $\mathrm{C}^{3+}$ DOPED YTTRIUM ALUMINIUM PEROVSKITE
}

\author{
J.A. MARES, M. NIKL and K. BLAZEK* \\ Institute of Physics, Czechoslovak Academy of Sciences, Na Slovance 2, 18040 Prague 8, \\ Czechoslovakia \\ "Monoknystaly Tumov, Palackeho 175, 51119 Tumov, Czechoslovakia
}

optical properties of $\mathrm{ce}^{3+}$ in yttrilum alumirium perovskite (YAlO ${ }_{3}$ ) are known in the VUV, $N$ and visible ranges in detail [1-3]. There were studied emission properties of several $\mathrm{Ce}^{3+},\left(\mathrm{Ce}^{3+}, \mathrm{Nd}^{3+}\right)$ and $\left(\mathrm{Ce}^{3+}, \mathrm{Nd}^{3+} \cdot \mathrm{Cr}^{3+}\right.$ ) doped $\mathrm{YAlO}_{3}$ crystals (4f $\rightleftarrows$ Ed transitions) together with transfer processes between various $\mathrm{Ce}^{3+}$ multisites under hydrogen. I amp excitation on the spectrofluorometer Model $199 \mathrm{~s}$ Edinburgh Instruments in the UV and visible ranges in this paper.. New $\mathrm{Ce}^{3+} 5 \mathrm{~d} \rightarrow 4 \mathrm{f}$ emission band was observed on lightly $(\sim \mathrm{ppm})$ and heavily $(\sim 0.5$ at. $\%) \mathrm{Ce}^{3+}$ doped YAlO crystals for the first time. This emission band is broad (from 450 to $550 \mathrm{~nm}$ ), peaking at $500 \mathrm{~nm}$ at room temperature and its intensity increases with $\mathrm{Ce}^{3+}$ content. The fluorescence decay measurements show that it is caused by $\mathrm{Ce}^{3+}$ ions in $\mathrm{YAlO}_{3}$ because its fluorescence Iifetime is $\tau \doteq 14 \mathrm{~ns}$ which is much shorter than $\mathrm{Ce}^{3+}$ fluorescence Iifetime in $Y_{3} A_{s} O_{12}$ :Ce where. $\tau \doteq 50 \mathrm{~ns}$. The $\mathrm{Ce}^{3+}$ green emission band disappears in $\mathrm{YAlO}_{3}$ : Ce crystals codoped with Nd and $\mathrm{Cr}$.

From spectroscopic measurements the energy level scheme of new $\mathrm{Ce}^{3+}$ centres in YAlO crystals was determined. Generally, we can resolve two $\mathrm{Ce}^{3+}$ multisites in YAlO from which the first one is radiating in the UV (major centres) and the second one in the green (minor centres). The radiative energy transfer was observed between $C e^{3+}$ multisites (from $\mathrm{Ce}^{3+}(\mathrm{UV})$ to $\mathrm{Ce}^{3+}$ (green) centres). A structure of the $\mathrm{Ce}^{3+}$ multisites will be discussed. The $\mathrm{Ce}^{3+}$ multisites responsible for green emission could be caused either die to $\mathrm{Ce}^{3+}$ pairs (less probable) or due to $\mathrm{Ce}^{3+}$ centres where two $\mathrm{Ce}^{3+}$ ions are binded via $\mathrm{O}^{2-}$ ions from $\mathrm{YAlO}_{3}$ lattice (more probable case). FEFERENCES

[1j M.J. Weber, J. Appl. Phys. 44 (1973) 3205-3208).

[2] R. Autrata, F. Schauer, Jos. Kvapil and J. Kvapil, Cryst. Res.' Technol. 18 (1983), 907-913.

[3] J.A. Mares, M. Nikl, C. Pedrini, B. Moine and K. Blazek, to be Dublished. 